\title{
ESCO - A TOOL TO CONNECT EDUCATION WITH EMPLOYMENT
}

\author{
Petrică Sorin ANGHELUȚ $\breve{A}^{a}$, Alina Georgiana PROFIROIU \\ Petruț Cristian VASILACHEc, Corneliu GUT⿱宀 ${ }^{d}$, \\ Vasile P $\breve{A U N} A^{e}$ \\ a,b,c,e Bucharest University of Economic Studies, Romania \\ ${ }^{d}$ Academy of Economic Studies of Moldova
}

\begin{abstract}
The European Commission's interest in connecting education with the labor market has materialized through the development of a tool that uses terminology common to both areas. Thus, the European Skills / Competences, Qualifications and Occupations (ESCO) has been developed to help transparency and the recognition of competencies and qualifications. At the same time, the aim is to make the labor market more integrated and efficient. Many times, high school graduates, when they choose to continue their studies at a higher level, do not know what skills and competencies they will acquire after graduating from university specialization. For this reason, the article aims to describe European Skills / Competences, Qualifications and Occupations. Also, taking into account this European classification, as well as the importance that the population with higher education may have on a community, an analysis is made of the current situation of the population with tertiary education level in the member countries of the European Union. The areas in which students are trained can influence the development of new jobs. The article examines, at European level, the areas of education for which tertiary education graduates have been trained.
\end{abstract}

KEYWORDS: education, labor market, European Union

\section{INTRODUCTION}

At the level of the European Commission, the Directorate-General for Employment, Social Affairs and Inclusion has led, and carried out, an important project both for the labor market and for European education and training systems. It is about European Skills / Competences, Qualifications and Occupations (ESCO). The existing information in the ESCO can be consulted free of charge, through a specific portal. In 2013, the first version of this classification was published.

Using common labor market terminology and vocational education and training terminology, ESCO allows for improvement, integration and communication between the two systems.

Through ESCO are connected different classifications: International Standard Classification of Occupations (ISCO), International Standard Classification of Education: Fields of Education and Training (ISCED), European Qualifications Framework (EQF).

ESCO also supports the implementation of two important European documents: Europe 2020 and Skills agenda for Europe (EC, 2020b).

By the way it has been developed, in Europe, ESCO supports job mobility. Thus, the labor market becomes more integrated and efficient.

ESCO helps at the transparency and the recognition of competencies and qualifications.

\footnotetext{
${ }^{*}$ Corresponding author. E-mail address: sorin.angheluta@gmail.com
} 


\section{LITERATURE REVIEW}

In recent years, there has been an increase in the geographical and professional mobility of people. Thus, due to the need for new skills, more often than in the past, people change their employer, respectively their job. Digital tools are also increasingly used to publish job vacancies and for apply them. Thus, clear and up-to-date information on skills and qualifications is needed.

Existing descriptions in the ESCO provide an opportunity to identify the knowledge and skills needed to work in a particular occupation. This classification also provides a list of those knowledge, skills, and competencies that a person acquires upon completion of a qualification program. People who want to requalified or want to upgrade their skills have the opportunity to find out through the ESCO which jobs they can fill with the skills they have acquired. A uniform approach to the construction of work processes and European qualification systems can be achieved through tools that take into account both areas (Clarke et al., 2020). The ESCO classification can also be used to make job descriptions, necessary for writing CVs and job offers, respectively. Employers are thus better informed about the requirements they can impose on accessing jobs within companies. The availability of information from the ESCO in several foreign languages allows it to promote mobility and connect labor markets. Thus, people who want to work in another European country have the opportunity to better communicate their skills and training. The added value that ESCO offers, both to the labor market and to education and training systems, is given by the continuous improvement of the information contained in this classification. People looking for a job, through common terminology, have the opportunity to use ESCO for this purpose. ESCO is available free of charge to all organizations in the labor market and education. All stakeholders in both the labor market and education can participate in the development of the ESCO.

An additional quality of this classification is given by the recognition of both informal and non-formal learning.

By describing skills, competences and qualifications, ESCO supports the transition from education to work. Employment opportunities, as well as those related to learning, increase through the application of measures regarding transparency and the recognition of competences and qualifications. Job mobility can increase to the extent that work experiences can be certified based on acquired skills (Bratsberg et al., 2020). The visibility of skills and qualifications can be enhanced by the support provided by vocational education and training tools and systems.

\section{RESEARCH METHODOLOGY}

Graduating an university level of specialization requires the acquisition of skills and competence. In most cases, the choice of university specializations by high school graduates is not made knowingly. The article describes European Skills / Competences, Qualifications and Occupations. The population with higher education has a high influence at the level of any community, including the European community. Thus, an analysis of the current situation of the population with tertiary education level in the member countries of the European Union is presented. At the same time, the fields of education for which tertiary education graduates were trained are analyzed.

\section{RESULTS AND DISCUSSION}

ESCO is a component part of the Europe 2020 Strategy. Within this classification, skills, competences, qualifications and occupations are identified and divided into categories. Those qualifications and occupations that are relevant both to the labor market in the European Union and to European vocational education and training are taken into account. Thus, the relationships between the different concepts are indicated systematically (EC, 2020a). 
ESCO is also developed at European level, in a multilingual system. Within ESCO, descriptions and classifications are made for both occupations and skills and qualifications. Their identification was made taking into account their relevance for the labor market, as well as for education and training. Integration into an electronic system has allowed ESCO to be used by various online platforms.

The ESCO classification is in a continuous update of information. The version launched in July 2020 describes 2942 occupations, 10583 skills / competences and 2902 knowledge. The information is provided in the 24 official languages of the European Union, but also in Icelandic, Norwegian and Arabic (EC, 2020c). Using learning outcomes made the qualifications in tertiary education should be based on competencies (Méhaut \& Winch, 2012). In this sense, the ESCO classification is used more and more often. In Italy, Docebo is a platform that, in order to identify employee training requirements, has combined artificial intelligence and ESCO classification. It shows how ESCO helps to identify the qualification needs of employees, but also how ESCO contributes to changing the content of training in order to complete the qualification needs (EC, 2018a). In Iceland, the ESCO classification has been introduced at national level. In this country, ESCO is used to renew existing information on work platforms. In this way, in order to achieve a better job matching, employers and job seekers can more easily connect with each other (EC, 2018b).

Table 1. Comparative situation of the population from 15 to 64 years with tertiary education (levels 5-8), for the year 2004, respectively for the year 2019 (\%)

\begin{tabular}{|c|c|c|}
\hline Countries & $\mathbf{2 0 0 4}$ & $\mathbf{2 0 1 9}$ \\
\hline European Union & 18.2 & 27.9 \\
\hline Belgium & 26.8 & 36.0 \\
\hline Bulgaria & 17.9 & 24.7 \\
\hline Czechia & 10.4 & 21.6 \\
\hline Denmark & 27.9 & 33.1 \\
\hline Germany & 21.1 & 25.9 \\
\hline Estonia & 25.6 & 36.5 \\
\hline Ireland & 24.9 & 40.7 \\
\hline Greece & 17.5 & 27.8 \\
\hline Spain & 24.5 & 35.1 \\
\hline France & 22.7 & 33.7 \\
\hline Croatia & 13.2 & 22.0 \\
\hline Italy & 10.0 & 17.4 \\
\hline Cyprus & 25.7 & 40.0 \\
\hline Latvia & 16.5 & 31.4 \\
\hline Lithuania & 21.6 & 37.9 \\
\hline Luxembourg & 20.8 & 41.0 \\
\hline Hungary & 14.2 & 22.5 \\
\hline Malta & 10.2 & 26.1 \\
\hline Netherlands & 25.7 & 34.8 \\
\hline Austria & 15.4 & 31.1 \\
\hline Poland & 12.8 & 28.2 \\
\hline Portugal & 10.8 & 23.8 \\
\hline Romania & 8.7 & 16.0 \\
\hline Slovenia & 15.7 & 29.3 \\
\hline Slovakia & 10.4 & 23.1 \\
\hline Finland & 28.3 & 38.5 \\
\hline Sweden & 24.7 & 37.8 \\
\hline
\end{tabular}

Source: made by the authors based on existing data on the EUROSTAT website (2020) 
In Romania, the ESCO classification is used in the field of vocational education and training. Thus, the occupational standard contains the main tasks and responsibilities specific to an occupation. This information is correlated with those existing in ISCO, Classification of Occupations in Romania (COR), respectively ESCO. Also, in higher education, similarly, the acquired qualification must be correlated with existing occupations in ISCO, COR, respectively ESCO (NQA, 2020). Through the description made with the help of learning outcomes, qualifications are more transparent. Matching people's knowledge, skills and competencies with those required in the workplace becomes much easier. It also increases the accuracy with which employers specify the skills and qualifications they expect from employees. The percentage of the population with tertiary education level is important for any analysis in the field of education. The Table 1 shows the comparative situation of the population from 15 to 64 years with tertiary education (levels 5-8), for 2004, respectively for 2019 (\%). From the data presented in the previous table, it is observed that, in 2019 compared to 2004, the population from 15 to 64 years with tertiary education (levels 5-8) increased in all member states of the European Union. The largest increases were recorded in: Luxembourg $(+20.2 \%)$, Lithuania $(+16.3 \%)$, Malta $(+15.9 \%)$, Ireland $(+15.8 \%)$, Austria $(+15.7 \%)$, Poland $(+15.4 \%)$. At the same time, the lowest increases were registered in: Germany $(+4.8 \%)$, Denmark $(+5.2 \%)$, Bulgaria $(+6.8 \%)$, Romania $(+7.3 \%)$, Italy $(+7.4 \%)$. However, in 2019 , the countries where the population from 15 to 64 years with tertiary education was most numerous are: Luxembourg $(41.0 \%)$, Ireland $(40.7 \%)$, Cyprus (40.0\%), Finland (38.5\%), Lithuania (37.9\%). In 2019, the countries with the fewest people from 15 to 64 years with tertiary education are: Romania (16.0\%), Italy (17.4\%), Czechia (21.6\%), Croatia (22.0\%), Hungary (22.5\%), Slovakia (23.1\%), Portugal (23.8\%), Bulgaria (24.7\%).

Table 2. The comparative situation of bachelor's graduates or equivalent level, for 2013, respectively for 2018

\begin{tabular}{|c|c|c|}
\hline Countries & $\mathbf{2 0 1 3}$ & $\mathbf{2 0 1 8}$ \\
\hline European Union & 2017783 & 2035114 \\
\hline Belgium & 65947 & 69797 \\
\hline Bulgaria & 38303 & 29700 \\
\hline Czechia & 58270 & 40293 \\
\hline Denmark & 38806 & 44223 \\
\hline Germany & 283959 & 320295 \\
\hline Estonia & 7522 & 5499 \\
\hline Ireland & 29391 & 47411 \\
\hline Greece & 53394 & 48004 \\
\hline Spain & 118294 & 179250 \\
\hline France & 239530 & 263033 \\
\hline Croatia & 19362 & 18409 \\
\hline Italy & 201652 & 223428 \\
\hline Cyprus & 3374 & 3098 \\
\hline Latvia & 12921 & 7671 \\
\hline Lithuania & 29810 & 18976 \\
\hline Luxembourg & 545 & 627 \\
\hline Hungary & 42683 & 40538 \\
\hline Malta & 2153 & 2383 \\
\hline Netherlands & 92323 & 104948 \\
\hline Austria & 27863 & 28593 \\
\hline Poland & 392182 & 314721 \\
\hline Portugal & 51467 & 48808 \\
\hline Romania & 97661 & 73430 \\
\hline Slovenia & 9799 & 8802 \\
\hline Slovakia & 32887 & 20556 \\
\hline Finland & 33669 & 37547 \\
\hline Sweden & 34016 & 35074 \\
\hline
\end{tabular}

Source: made by the authors based on existing data on the EUROSTAT website (2020) 
The skills that people need in the labor market are part of the job offer and the various analyzes and research. Thus, education and training providers can to a greater extent prepare students for the future labor market.

The Table 2 presents the comparative situation of the bachelor's or equivalent level graduates, for 2013, respectively for 2018 .

In 2018, compared to 2013, the number of bachelor's or equivalent level graduates did not increase in all countries. Thus, there were significant increases in: Spain $(+60956$ persons $)$, Germany $(+36336$ persons), France ( +23503 persons), Italy ( +21776 persons), Netherlands $(+12625$ persons). Compared to 2013, in 2018, the number of bachelor's graduates's or equivalent level decreased in: Poland (77461 persons), Romania (-24231 persons), Czech Republic (-17977 persons), Slovakia (-12331 persons), Lithuania (- 0834 persons).

The following figure shows the evolution of the number of bachelor's graduates or equivalent level for the period 2013-2018 for the countries where this indicator was the highest in 2018.

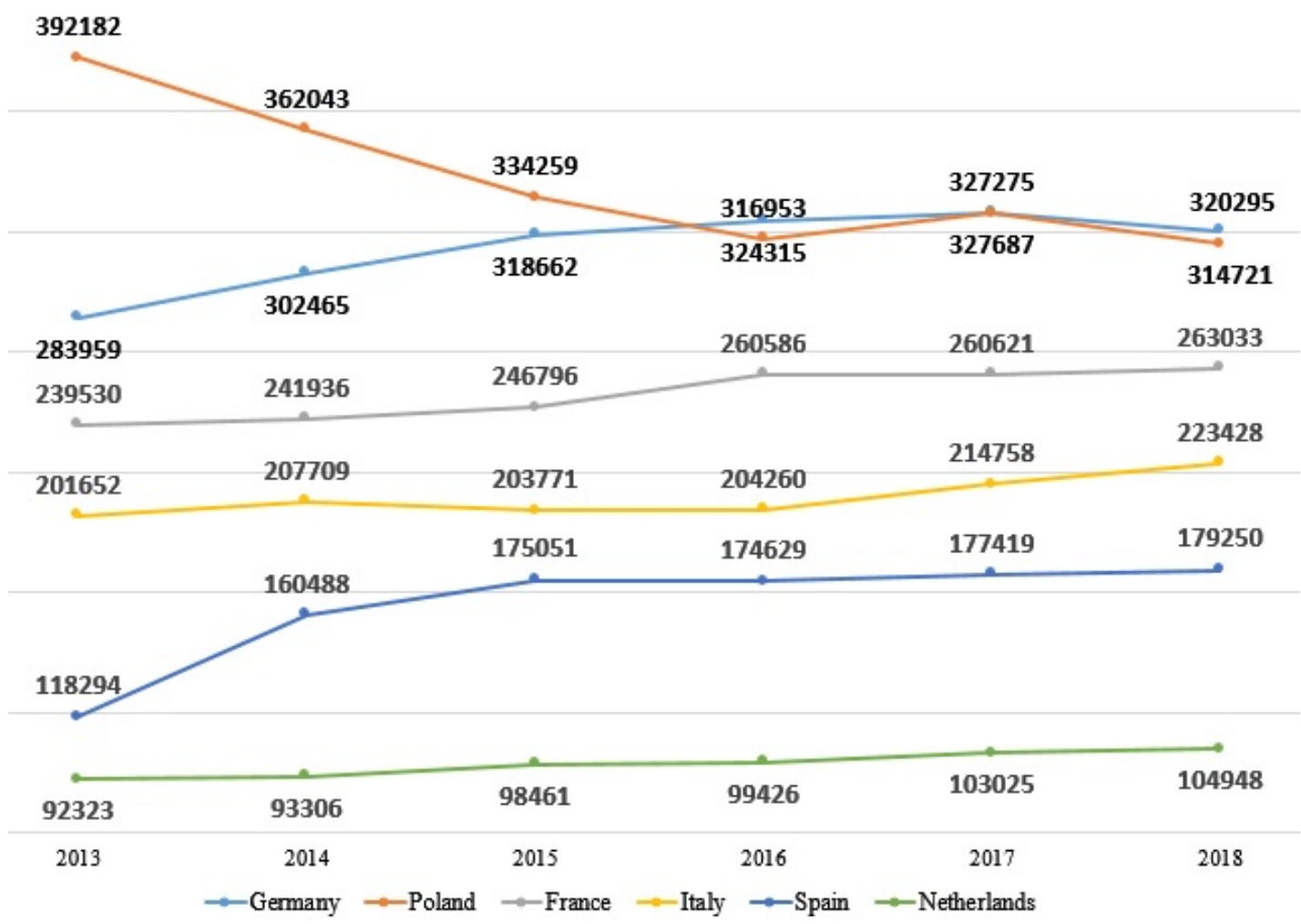

Figure 1. Evolution of the number of bachelor's graduates or equivalent level for the period 2013-2018 for the countries where this indicator was the highest in 2018

Source: made by the authors based on existing data on the EUROSTAT website (2020)

Compared to 2013, in 2018, only in Poland decreased the number of bachelor's graduates's or equivalent level (from 392182 to 314721 persons). For the other 5 countries there were increases in values. Thus, in 2018, most bachelor's or equivalent level graduates were in: Germany (320295 persons), Poland (314721 persons), France (263033 persons), Italy (223428 persons), Spain (179250 persons), Netherlands (104948 persons).

Regarding the fields of education of graduates, the Table 3 shows the distribution of tertiary education graduates by field of education, for $2018(\%)$.

At European level, it is observed that most graduates are in business, administration and law $(24.6 \%)$, followed by engineering, manufacturing and construction $(15.2 \%)$. 
Depending on the educational field, at European level, compared to the total number of graduates from each country, for the field of education, most graduates are in Poland, Cyprus, Spain.

Table 3. Distribution of tertiary education graduates by field of education, for 2018 (\%)

\begin{tabular}{|c|c|c|c|c|c|c|c|c|c|c|}
\hline $\mathbf{1}$ & $\mathbf{2}$ & $\mathbf{3}$ & $\mathbf{4}$ & $\mathbf{5}$ & $\mathbf{6}$ & $\mathbf{7}$ & $\mathbf{8}$ & $\mathbf{9}$ & $\mathbf{1 0}$ & $\mathbf{1 1}$ \\
\hline European Union & 10.3 & 9.8 & 9.2 & 24.6 & 6.4 & 3.8 & 15.2 & 1.9 & 13.7 & 4.7 \\
\hline Belgium & 7.9 & 9.3 & 10.2 & 20.3 & 3.7 & 2.1 & 11.2 & 2.0 & 28.8 & 1.3 \\
\hline Bulgaria & 9.4 & 6.5 & 13.1 & 31.8 & 3.1 & 3.8 & 12.4 & 1.9 & 9.4 & 8.5 \\
\hline Czechia & 11.4 & 8.7 & 11.0 & 19.9 & 5.7 & 4.9 & 15.5 & 3.4 & 12.2 & 7.3 \\
\hline Denmark & 5.2 & 11.5 & 10.0 & 25.6 & 5.4 & 4.8 & 12.0 & 1.2 & 20.9 & 3.1 \\
\hline Germany & 11.2 & 11.4 & 7.5 & 22.7 & 9.0 & 4.9 & 21.4 & 1.8 & 7.4 & 2.5 \\
\hline Estonia & 7.3 & 13.1 & 8.0 & 22.8 & 6.3 & 6.7 & 14.8 & 1.7 & 12.5 & 6.8 \\
\hline Ireland & 8.6 & 11.6 & 5.8 & 26.7 & 7.6 & 7.9 & 8.6 & 1.5 & 16.8 & 4.1 \\
\hline Greece & 7.9 & 11.2 & 13.9 & 21.9 & 9.1 & 3.1 & 16.1 & 2.7 & 11.1 & 3.0 \\
\hline Spain & 17.0 & 8.9 & 7.0 & 19.3 & 5.2 & 3.9 & 13.1 & 1.1 & 16.8 & 7.5 \\
\hline France & 4.1 & 8.6 & 7.4 & 34.3 & 8.0 & 3.5 & 13.9 & 1.6 & 14.5 & 3.9 \\
\hline Croatia & 6.9 & 8.7 & 7.6 & 25.2 & 5.1 & 4.0 & 17.2 & 3.6 & 11.8 & 9.9 \\
\hline Italy & 6.9 & 16.8 & 14.3 & 17.7 & 7.6 & 1.3 & 15.4 & 2.5 & 14.5 & 2.6 \\
\hline Cyprus & 19.6 & 7.0 & 7.2 & 39.0 & 2.5 & 2.6 & 10.1 & 0.8 & 6.2 & 5.1 \\
\hline Latvia & 7.7 & 7.1 & 8.9 & 28.5 & 2.7 & 4.7 & 12.7 & 2.2 & 17.5 & 8.0 \\
\hline Lithuania & 5.9 & 8.5 & 9.0 & 25.6 & 4.3 & 3.1 & 19.4 & 3.3 & 18.0 & 2.8 \\
\hline Luxembourg & 10.1 & 10.0 & 10.7 & 42.5 & 5.8 & 5.8 & 7.2 & 0.2 & 6.8 & 0.9 \\
\hline Hungary & 14.1 & 9.0 & 10.2 & 25.4 & 3.9 & 4.6 & 14.0 & 4.0 & 8.6 & 4.8 \\
\hline Malta & 5.2 & 9.8 & 10.5 & 31.3 & 4.7 & 7.0 & 8.9 & 0.3 & 19.9 & 2.3 \\
\hline Netherlands & 9.7 & 8.7 & 13.4 & 27.2 & 6.4 & 2.8 & 8.2 & 1.3 & 17.1 & 5.1 \\
\hline Austria & 11.6 & 8.1 & 7.2 & 24.3 & 6.1 & 4.4 & 20.6 & 1.6 & 8.4 & 7.6 \\
\hline Poland & 20.6 & 7.0 & 8.9 & 23.5 & 3.3 & 3.8 & 14.5 & 1.8 & 8.9 & 7.4 \\
\hline Portugal & 4.4 & 10.1 & 11.2 & 20.3 & 6.1 & 2.2 & 19.6 & 2.3 & 17.5 & 6.3 \\
\hline Romania & 4.5 & 9.1 & 9.2 & 26.7 & 5.2 & 5.8 & 17.1 & 4.2 & 13.4 & 4.8 \\
\hline Slovenia & 11.1 & 9.0 & 9.3 & 20.5 & 6.6 & 3.5 & 17.2 & 3.0 & 12.1 & 7.8 \\
\hline Slovakia & 13.7 & 7.6 & 11.8 & 20.1 & 5.7 & 3.9 & 12.4 & 2.3 & 16.5 & 6.0 \\
\hline Finland & 6.8 & 10.5 & 7.1 & 18.8 & 4.6 & 7.0 & 16.5 & 2.1 & 21.9 & 4.6 \\
\hline Sweden & 13.0 & 5.6 & 11.8 & 16.4 & 4.1 & 4.3 & 18.3 & 0.8 & 23.2 & 2.4 \\
\hline
\end{tabular}

Source: made by the authors based on existing data on the EUROSTAT website (2020)

The meaning of the columns is as follows:

1 - Countries;

2 - Education

3 - Arts and humanities

4 - Social sciences, journalism and information

5 - Business, administration and law

6 - Natural sciences, mathematics and statistics

7 - Information and Communication Technologies

8 - Engineering, manufacturing and construction

9 - Agriculture, forestry, fisheries and veterinary

10 - Health and welfare

11 - Services 
In the field of arts and humanities, Italy and Estonia have the most graduates. The highest values for the social sciences, journalism and information are registered in: Italy, Greece, Netherlands and Bulgaria. For business, administration and law, high values are in: Luxembourg, Cyprus, France, Bulgaria, Malta. Also, Greece, Germany, France and Italy have the most graduates in the natural sciences, mathematics and statistics. In the field of information and communication technologies, Ireland, Malta, Finland and Estonia have the highest values. At the same time, Germany, Austria, Portugal, Lithuania have the most graduates in the field of engineering, manufacturing and construction. Out of the total number of graduates from Romania, Hungary, Croatia, Czechia, graduates in agriculture, forestry, fisheries and veterinary are more numerous than those from other countries. Belgium, Sweden and Finland also have the most graduates in the field of Health and welfare, and Croatia, Bulgaria and Latvia, in the field of Services.

At the same time, it is observed that in 24 countries most graduates are in the field of business, administration and law. The 3 countries in which the field of health and welfare is predominant are: Belgium, Sweden and Finland.

\section{CONCLUSIONS}

Through the ESCO, the European Commission contributes to the implementation of labor market policies (EC, 2020d). Thus, in Europe, transparency and comparability of skills and occupations can be applied. At the same time, by reducing the gap between the labor market and vocational education and training systems, the mobility of people within the Member States of the European Union is increasing. The advantages of using the ESCO are also evident in the correlation between the supply of skills in the workforce, on the one hand, and the demand for skills of employers. The skills required by the labor market can be mentioned in training programs, so that education and training systems can meet these needs. Following the analysis, it was found that in 2019 compared to 2004, the population from 15 to 64 years with tertiary education (levels 5-8) increased in all member states of the European Union. Also, in 2018, compared to 2013, the number of bachelor's or equivalent level graduates did not increase in all countries. In 2018, most bachelor's or equivalent level graduates came from: Germany, Poland, France, Italy, Spain, Netherlands. At European level, it was observed that, in 2018, most graduates are in the field of business, administration and law, followed by engineering, manufacturing and construction. The Fourth Industrial Revolution calls for the development of European tertiary education skills to take into account basic generic skills, cognitive skills, and employment skills (Garcia-Esteban \& Jahnke, 2020). The use of information from the ESCO classification, as well as the involvement of as many organizations and institutions as possible in updating this information, can help to increase the recognition of competences and qualifications at European level. The article draws attention to the importance of high school graduates' knowledge of the skills offered by different university specializations.

The limitations of this article refer to the information uploaded to the ESCO portal. To the extent that most EU Member States enter information into the ESCO portal, it is considered to be more relevant to the European labor market.

\section{REFERENCES}

Bratsberg, B., Nyen, T., \& Raaum, O. (2020). Economic returns to adult vocational qualifications. Journal of Education and Work, 33(2), 99-114.

Clarke, L., Sahin-Dikmen, M., \& Winch, C. (2020). Overcoming diverse approaches to vocational education and training to combat climate change: the case of low energy construction in Europe. Oxford Review of Education.

European Commission. (2018a). How ESCO supports online corporate training - Docebo, Italy. Retrieved July 15, 2020, from https://audiovisual.ec.europa.eu/en/video/I-163051 
European Commission. (2018b). How ESCO supports the Public Employment Service of Iceland. Retrieved July 14, 2020, from https://audiovisual.ec.europa.eu/en/video/I-162745

European Commission. (2020a). Get to know ESCO. Retrieved July 15, 2020, from https://ec.europa.eu/esco/portal/home

European Commission. (2020b). European Skills/Competences, Qualifications and Occupations (ESCO). Retrieved July 14, 2020, from https://ec.europa.eu/social/main.jsp?catId=1326\&langId=en

European Commission. (2020c). Version 1.0.7. Retrieved July 14, 2020, from https://ec.europa.eu/esco/portal/version

European Commission. (2020d). ESCO use cases. Retrieved July 14, 2020, from https://ec.europa.eu/esco/portal/howtouse/bfe2a816-f9dd-49df-a7d2-ec8fafcfce95

EUROSTAT. (2020). http://ec.europa.eu/eurostat

Garcia-Esteban, S., \& Jahnke, S. (2020). Skills in European higher education mobility programmes: outlining a conceptual framework. Higher Education, Skills and Work-Based Learning, 10(3), 519-539.

Méhaut, P., \& Winch, C., (2012). The European Qualification Framework: skills, competences or knowledge? European Educational Research Journal, 11(3), 369-381.

National Qualifications Authority. (2020). Retrieved on Oct $10^{\text {th }}$ from http://www.anc.edu.ro 